\title{
Development of an Extractive Spectrophotometric Method for the Determination of Copper(II) in Leafy Vegetable and Pharmaceutical Samples Using 2-acetylpyridine 4-phenyl-3-thiosemicarbazone (APPT)
}

\author{
Nagarjuna Reddy, $\mathrm{D}^{\mathbf{1} *}$ and Vasudeva Reddy, $\mathrm{K}^{\mathbf{2}}$ \\ ${ }^{1}$ Department of Chemistry, Analytical division, Mekelle University, Mekelle, Ethiopia. \\ ${ }^{2}$ Department of Chemistry, Govt College of Women, Chinthamani, Karnataka. \\ (*dndnrchem@gmail.com)
}

\begin{abstract}
A highly sensitive extractive spectrophotometric method has been developed for the determination of copper(II) using 2-acetylpyridine-4-phenyl-3-thiosemicarbazone as an analytical reagent. The APPT forms reddish brown complex of copper(II) at a $\mathrm{pH}$ range of 3.05.5 , and the complex was extracted into n-butanol. The $\mathrm{Cu}(\mathrm{II})$-APPT complex shows maximum absorbance at $440 \mathrm{~nm}$, with molar absorptivity and Sandell's sensitivity being $2.16 \times 10^{4} \mathrm{~L} \mathrm{~mol}^{-1}$ $\mathrm{cm}-1$ and $2.94 \times 10^{-3} \mu \mathrm{g} \mathrm{cm}^{-2}$,respectively. The system obeys Beer's law in the range of 0.2-5.0 $\mathrm{mg} / \mathrm{L}$. The regression coefficient of the Beer's law straight line is 0.338 , and the correlation coefficient is 0.96 . The detection limit of the method is $0.0065 \mu \mathrm{g} \mathrm{mL}{ }^{-1}$. Most of the common metal ions generally found associated with copper do not interfere. The repeatability of the method was checked by finding the relative standard deviation. The developed method has been successfully employed for the determination of copper (II) in leafy vegetable and pharmaceutical samples. The method is evaluated by analyzing samples from the Bureau of Analyzed Samples (BCS 233, 266, 216/1, 207, and 179) and by inter-comparison of experimental values using AAS.
\end{abstract}

Keywords: $\mathrm{Cu}$ (II), leafy vegetables, Pharmaceuticals,Extractive spectrophotometric method, 2acetylpyridine-4-phenyl-3-thiosemicarbazone (APPT).

\section{INTRODUCTION}

Copper is one of several metal ions that play an important role in the biological system. It plays a key role during cell respiration, in the blood of invertebrate animals, and in the formation of hemocyanin, an important respiratory protein, found in the lymph of most animals belonging to Phyla Mollusca and Arthropoda. From the standpoint of human health, its role in three physiological functions is of prime importance. Copper is involved in hemopoiesis and in maintenance of vascular and skeletal integrity in addition to the structure and function of the central nervous system. Copper occurs naturally in most vegetables, meats, and grains. The study of copper in food items is of great concern, because it plays a definitive role in the intrinsic mechanisms regulating vital biological processes (Malvankar et al., 1991). Over exposure to copper causes metallic taste, ptyalism, nausea, vomiting, epigastric burning, and diarrhea. Heavy 
doses of copper cause a series of systematic toxic effects such as hemolysis, hepatic neurosis, gastrointestinal bleeding, oliguria azotemia, hemoglobin, urea, hematuria, proteinuria, hypertension, tachycardia, convulsions, and coma. When a congenital deficiency in the homeostatic mechanism for copper exists, the metal accumulates in the liver, discrete areas of the brain, the cornea of the eye, and other tissues, causing Wilson's disease. A wide variety of clinical disorders have been associated with a dietary deficiency of copper, which respond to copper therapy. They include anemia, depressed growth, bone disorders, de-pigmentation of hair or wool, abnormal wool growth, neonatal ataxia, impaired reproductive performance, heart failure, and gastrointestinal disturbances (Walravens et al., 1980). In view of this, the separation and determination of copper from associated elements is indispensable. For the determination of copper at micro levels there are several frequently adopted methods using analytical techniques such as AAS, ICP-OES, X-ray fluorescence spectrophotometry, spectrofluorometry, and other such techniques. Among these, the spectrophotometric methods are preferred as they are cheaper and easier to handle and have comparable sensitivity. A number of spectrophotometric reagents have been used for the determination of copper(II), but a very few number are used for the separation and determination of it. Thio and phenylthiosemicarbazones are important sulfur- and nitrogen-containing organic reagents, where copper coordinates with these reagents to form stable complexes. As it is more stable in its divalent state, it is extracted into organic solvents such as chloroform, $n$-butanol, and others as a divalent complex. The metal chelates of these sulfur- and nitrogen-containing organic reagents find a wide range of applications in medicine (Hall et al., 2000) and agriculture. The reviewed (Singh et al., 1978; Casas et al., 2000) literature revealed that only a few thio and phenyl thiosemicarbazones were employed for extractive determination of copper(II) (Khasnis et al., 1982; Jadhav et al., 1995; Thimmaiah et al., 1983; Khasnis et al., 1984; Tongsen et al., 1999; Lopez-de-Alba et al., 1999; Desai et al., 1999; Patel et al.,2000; Lokhande et al., 2001; Reddy et al., 2003). Hence, the authors introduced a new reagent, 2-acetylpyridine-4-phenyl-3-thiosemicarbazone (APPT), for the selective and spectrophotometric determination of $\mathrm{Cu}(\mathrm{II})$ in leafy vegetable, pharmaceutical, and Bureau of Analyzed samples. Our previous studies of transition metal ions such as zinc, cobalt and palladium extracted from biological and environmental samples using APPT were established (Reddy et al., 2002; Sarma et al., 2002; Sarma et al., 2003; Sarma et al., 2000). 


\section{MATERIALS AND METHODS}

\subsection{Apparatus and Reagents}

A Shimadzu $240 \mathrm{UV}-\mathrm{V}$ is spectrophotometer with a $1.0 \mathrm{~cm}$ quartz cell was used for absorbance studies. AnElico LI-120 digital pH-meter was used for $\mathrm{pH}$ adjustment. Results are compared with the data generated for the same using Perkin-Elmer 2380 atomic absorption spectrophotometer. All reagents used were of analytical reagent grade unless otherwise stated.

\subsection{Synthesis of 2-acetylpyridien-4-phenyl-3-thiosemicarbazone}

The chelating agent used for complexation in the present study is APPT. It is prepared as per the procedure reported by Cristofol et al. 1991. One gram of 2-acetylpyridine was dissolved in 15 $\mathrm{mL}$ of de-mineralized double distilled water (DDW) and mixed in a flask with $50 \mathrm{~mL}$ of ethanol containing $0.8 \mathrm{~g}$ of4-phenyl-3-thiosemicarbazide. The resulting solution was neutralized with sodium acetate and refluxed at $80^{\circ} \mathrm{C}$ for $30 \mathrm{~min}$. It was allowed to cool to room temperature until yellow crystals were formed. These were separated and recrystallized from ethanol (Scheme 1).<smiles>CC(=O)c1ccccn1</smiles>

2-acetylpyridine

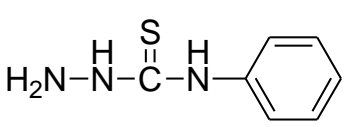

4-phenyl-3thiosemicarbazide

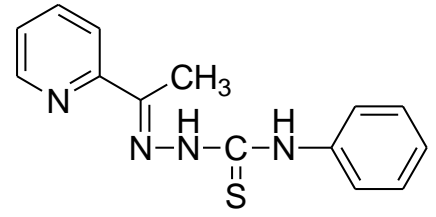

2-acetylpyridine-4-phenyl-3thiosemicarbazone

\subsection{Stock Solution of Copper Sulfate}

The stock solution was prepared by dissolving $3.93 \mathrm{~g}$ of copper sulfate pentahydrate $\left(\mathrm{CuSO}_{4} 5 \mathrm{H}_{2} \mathrm{O}\right)$ in DDW containing a few drops of concentrated sulfuric acid. The solution was made up to $1 \mathrm{~L}$ and standardized by iodometry (Vogel et al., 1961). This stock solution was diluted further, whenever necessary, with DDW.

\subsection{General Procedure}

To an aliquot of solution containing 10-150 $\mu \mathrm{g}$ of copper(II) were added sodium acetate and acetic acid buffer of $\mathrm{pH} 4.5$ and $0.5 \%$ reagent solutions $(0.4 \mathrm{~mL})$; the mixture was shaken with $n$ butanol $(2 \times 5 \mathrm{~mL})$ for $1 \mathrm{~min}$ and allowed to stand for a few minutes. The organic phases were then separated, combined, and made up to $25 \mathrm{~mL}$ with $n$-butanol and its absorbance was measured at $440 \mathrm{~nm}$ against the reagent blank. 


\section{RESULTS AND DISCUSSION}

Copper(II) forms a reddish brown 1:1 (M:L) complex with APPT, which was extracted well into $n$-butanol from sodium acetate-acetic acid buffer of $\mathrm{pH} 4.5$. The colored complex in $n$-butanol showed a maximum absorbance at $440 \mathrm{~nm}$, when the spectrum of the complex was recorded, against the reagent blank. The color of the complex was stable for a minimum of $48 \mathrm{~h}$. The optimum conditions for the effective extraction of copper(II) were established by studying the effects of factors such as $\mathrm{pH}$, reagent concentration, choice of solvent, salting out agent, and interference of various diverse ions, to develop a sensitive and rapid extractive spectrophotometric method for the determination of copper(II). The proposed method when compared with other spectrophotometric methods (Table 1) was found to be more sensitive and selective. It also offers advantages such as reliability and reproducibility in addition to its simplicity, instant color development, and lower levels of interference.

\subsection{Absorption Spectra}

The absorption spectra of the $\mathrm{Cu}$ (II)-APPT complex are shown in figure 1. From the spectra, it is clear that the $\mathrm{Cu}$ (II)-APPT complex and the reagent have maximum absorbance at 440 and 320 $\mathrm{nm}$, respectively. The reagent has a minimum absorbance where the complex has maximum absorbance and does not interfere in the determination of $\mathrm{Cu}(\mathrm{II})$. Hence, further absorbance measurements of the complex were made at $440 \mathrm{~nm}$. Hence, all of the spectral measurements were carried out at this wavelength.

\subsection{Effect of $\mathrm{pH}$}

A preliminary study showed that the formation of the $\mathrm{Cu}$ (II)-APPT complex was affected by the hydrogen ion concentration. Extraction of copper(II) with APPT was carried out over a wide range of $\mathrm{pH}$ (1-10). It reveals that the extraction of copper(II) with APPT into $n$-butanol was maximum between $\mathrm{pH} 3.0$ and 5.5. Hence, all of the extractions were carried out at $\mathrm{pH} 4.5$, considering it as the optimum $\mathrm{pH}$.

\subsection{Effect of Solvents}

Solvents such as $n$-amyl alcohol, isoamylalcohol, benzene, $n$-butanol, butyl acetate, carbon tetrachloride, chloroform, chlorobenzene, cyclohexane, cyclohexanol, and methyl isobutyl ketone were prepared to extract $2.5 \mathrm{ppm}$ of copper(II) with APPT. As per the results reported in 
(Table 2), $n$-butanol was selected as the suitable solvent for effective extraction of the $\mathrm{Cu}(\mathrm{II})$ APPT complex. Hence, $n$-butanol was chosen for all further studies.

Table 1. Comparison of the present method with other spectrophtometric methods for the determination of Copper (Note: ${ }^{a} \mathrm{M}: \mathrm{L}$, metal/ligand; $\varepsilon^{*}=$ molar abssorptivity, $10^{4} \mathrm{~L} \mathrm{~mol}^{-}$ $\left.{ }^{1} \mathrm{~cm}^{-1}\right)$.

\begin{tabular}{|c|c|c|c|c|c|c|}
\hline Reagent & $\begin{array}{l}\lambda \\
\max \\
(n m)\end{array}$ & $\begin{array}{l}\mathrm{pH} \\
\text { range }\end{array}$ & $\begin{array}{l}\text { Beer's } \\
\text { law } \\
\text { validity } \\
\text { range } \\
\text { (ppm) }\end{array}$ & $\varepsilon^{*}$ & $M: L^{a}$ & $\operatorname{Ref}$ \\
\hline $\begin{array}{l}\text { Phenanthraquinone } \\
\text { monothiosemicarbonzone }\end{array}$ & 540 & 5.5 & $2.5-3.5$ & 1.16 & $1: 2$ & Khasnis et al., 1982 \\
\hline $\begin{array}{l}\text { 8-methoxy-2-chloroquinoline-3- } \\
\text { carbaldehyde thiosemicarbazone }\end{array}$ & 410 & 5.0 & 3.0 & 0.26 & $1: 1$ & Jadhav et al., 1995 \\
\hline p-anisaldehydethiosemicarbazone & 398 & - & $0.1-10.0$ & 0.61 & $1: 2$ & $\begin{array}{l}\text { Thimmaiah et al., } \\
1983\end{array}$ \\
\hline $\begin{array}{l}\text { Quinoline-2-aldehyde } \\
\text { thiosemicarbazone }\end{array}$ & 430 & 7.5 & $0.5-25.0$ & 1.3 & $1: 1$ & Khasnis et al., 1984 \\
\hline salicyladehyde thiosemicarbazone & 375 & $6.5-7.5$ & $0.5-6.0$ & 0.92 & $1: 1$ & Tongsen et al., 1999 \\
\hline $\begin{array}{l}\text { 5,51-dimethyl-1,2,3- } \\
\text { cyclohexanetrione-1,2-dioxime }\end{array}$ & 383 & & $0-11.2$ & 0.46 & $1: 3$ & $\begin{array}{l}\text { Lopez-de-Alba et al., } \\
1999\end{array}$ \\
\hline $\begin{array}{l}\text { 2,4-dihydroxy-5- } \\
\text { bromoacetophenone } \\
\text { Thiosemicarbazone }\end{array}$ & 420 & 6.0 & 12.7 & 0.14 & $1: 1$ & Desai et al., 1999 \\
\hline $\begin{array}{l}\text { Benyaldehyde-4-(2-hydroxy-5- } \\
\text { sulforphenyl)- } \\
\text { 3-thiosemicarbazone }\end{array}$ & 325 & 4.5 & 7.62 & 0.07 & $1: 2$ & Patel et al.,2000 \\
\hline $\begin{array}{l}\text { 4-choroisontirosoacetophenone } \\
\text { Thiosemicarbazone }\end{array}$ & 400 & $7.5-8.5$ & $0.2-20$ & 0.25 & $1: 2$ & $\begin{array}{l}\text { Lokhande et al., } \\
2001\end{array}$ \\
\hline Benzildithiosemicarbasone & 380 & 4.0 & $0.5-4.0$ & 1.6 & $1: 1$ & Reddy et al., 2003 \\
\hline $\begin{array}{l}\text { 2-acetylpyridine-4-phenyl-3- } \\
\text { thiosemicarbazone }\end{array}$ & 440 & $3.0-5.5$ & $0.2-5.0$ & 2.16 & $1: 1$ & Present Method \\
\hline
\end{tabular}

\subsection{Effect of Reagent Concentration}

The effect of reagent concentration on the formation of the $\mathrm{Cu}(\mathrm{II})$-APPT complex has been studied by keeping the amount of metal ion solution $(62.5 \mu \mathrm{g})$ and $3.0 \mathrm{~mL}$ of $\mathrm{pH} 4.5$ buffer constant and $1.0 \mathrm{~mol} / \mathrm{L}$ of APPT solution containing different concentrations ranging from0.983 $\mathrm{x} 10^{-3}$ to $9.83 \times 10^{-3} \mathrm{~mol} / \mathrm{L}$ in order to get the maximum color formation. The total volume of the organic phases was collected into $25 \mathrm{~mL}$ standard flasks. The organic phases were made up to 25 
$\mathrm{mL}$ with $n$-butanol, and the absorbances of these phases were measured at $440 \mathrm{~nm}$, against their corresponding reagent blanks. The results clearly indicate that a 7 -fold molar $\left(6.88 \times 10^{-3} \mathrm{~mol} / \mathrm{L}\right.$ APPT) excess of the reagent to that of metal ion is necessary for maximum color development of the $\mathrm{Cu}$-(II)-APPT complex. Hence, a 7-fold molar excess of the reagent was maintained for maximum extraction of copper(II).

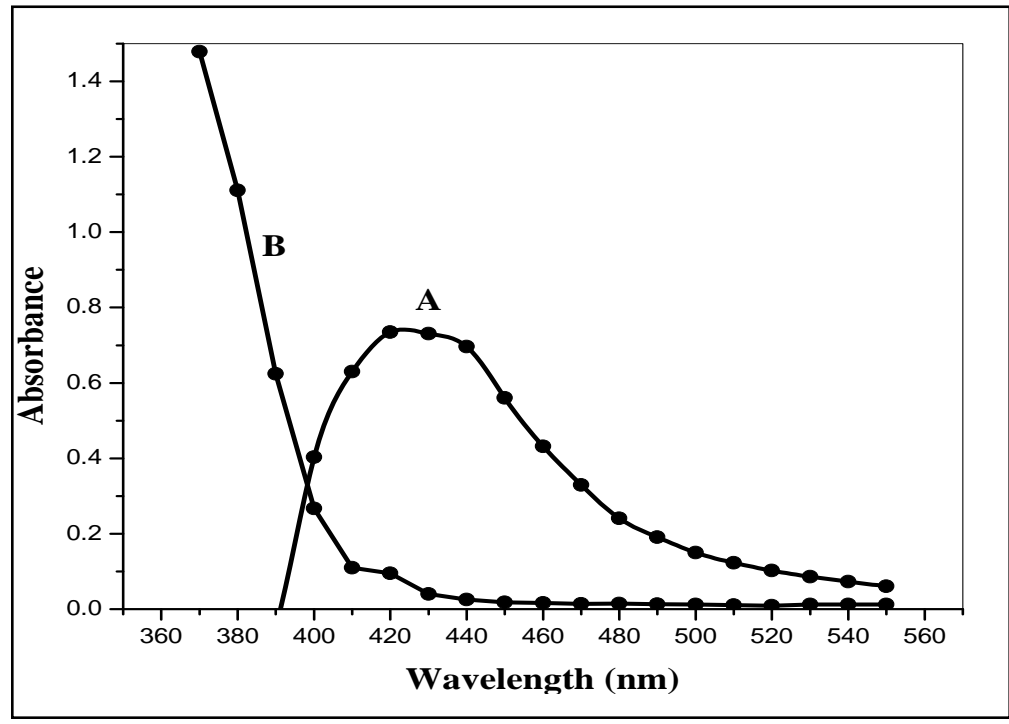

Figure 1.Absorption spectra of (A) Cu(II)-APPT complex versus APPT blank and (B) APPT versus n-butanol blank. $\mathrm{Cu}(\mathrm{II}), 1.0 \mathrm{~mL}$ of $0.98 \times 10^{-3} \mathrm{~mol} / \mathrm{L} ; \mathrm{pH}, 3.0 \mathrm{~mL}$ of 4.5 ; APPT, 2.0 $\mathrm{mL}$ of $1.97 \times 10^{-3} \mathrm{~mol} / \mathrm{L}$.

Table 2.Effect of Solvents on the Extraction of Cu(II)-APPT Complex ${ }^{\mathrm{a}}, \mathrm{Cu}(\mathrm{II}), 1.0 \mathrm{~mL}$ of $0.98^{\prime}$ 10-3 M; APPT, $2.0 \mathrm{~mL}$ of $3.44^{\prime} 10-3 \mathrm{M}$; $\mathrm{pH} 4.5$; $\lambda \max 440 \mathrm{~nm}$.

\begin{tabular}{|ll|}
\hline Solvent & Absorbance \\
\hline n-butanol & 0.850 \\
\hline Chlorobenzene & 0.475 \\
\hline carbon tetrachloride & 0.450 \\
\hline butyl acetate & 0.424 \\
\hline benzene & 0.372 \\
\hline isoamyl alcohol & 0.350 \\
\hline chloroform & 0.326 \\
\hline methyl isobutyl ketone & 0.275 \\
\hline n-amyl alcohol & 0.205 \\
\hline cyclohexane & 0.154 \\
\hline cyclohexanol & 0.142 \\
\hline
\end{tabular}




\subsection{Effect of Salting-out Agent}

Various salting-out agents, such as magnesium sulfate, lithium nitrate, lithium sulfate, lithium chloride, ammonium sulfate, sodium chloride, and sodium sulfate, were tested to enhance the metal-complex extraction into the organic phase, in a single step. It is noted that these salting-out agents have no significant effect on the absorbance of the colored solution. The absence of copper(II) in the aqueous phase after extraction was tested by using dithizone, spectrophotometrically, which discloses that there is no copper-(II) in it.

\subsection{Validity of Beer's Law, Molar Absorptivity, Sandell'sSensitivity, and Correlation Coefficient}

The present studies indicate that Beer's law was obeyed over the concentration range of 0.4-5.0 $\mathrm{mg} / \mathrm{L}$ of copper(II) with molar absorptivity and Sandell's sensitivity being $2.16 \times 10^{4} \mathrm{~L} \mathrm{~mol}^{-1} \mathrm{~cm}^{-}$

${ }^{1}$ and $2.94 \times 10^{-3} \mathrm{\mu} \mathrm{cm}^{-2}$ respectively. The regression coefficient of the Beer's law straight line is 0.338 , and the correlation coefficient is 0.96 . Good linearity with a correlation coefficient value of0.96 was obtained for the $\mathrm{Cu}(\mathrm{II})$-APPT complex. The calibration curve was prepared to determine the actual analyte content in real samples. The linear least-squares method, which states that the best straight line through a series of incremental points is that line for which the sum of the squares of the deviations of the points from the line is minimum, was used to prepare the calibration curve.

\subsection{Precision, Accuracy, and Detection Limit of the Method}

Five aliquots of different concentrations with seven samples for each concentration were taken, and copper(II) was determined employing the general procedure in order to assess the accuracy and precision of the method. The standard deviation of the method is found to be not more than 0.006 , and the relative standard deviation is less than $1.84 \%$. The values indicate that this method has a greater accuracy and enhanced precision. The detection limit, $C \mathrm{~min}$, was determined as the amount of copper-(II) corresponding to 3 times the deviation of blank values; a value of $6.5 \times 10^{-}$ ${ }^{2} \mu \mathrm{g} \mathrm{mL}{ }^{-1}$ was obtained.

\subsection{Determination of the Composition of the $\mathrm{Cu}$ (II)-APPT Complex.}

The composition of the $\mathrm{Cu}(\mathrm{II})$-APPT complex was studied by the method of Job's continuous variation and mole ratio methods. 


\subsubsection{Job's Method of Continuous Variation}

Equimolar $\left(2.95 \times 10^{-3} \mathrm{~mol} / \mathrm{L}\right)$ solutions of copper(II) and APPT were prepared. The metal and reagent solutions were mixed in different proportions, keeping the total volume of metal and ligand constant at $2.0 \mathrm{~mL}$. In each case, $3.0 \mathrm{~mL}$ of sodium acetate aceticacid buffer ( $\mathrm{pH} 4.5)$ was added to the mixture, and the volume of the aqueous phase was brought to $10.0 \mathrm{~mL}$ with doubledistilled water. Each of the above aqueous phases was shaken thoroughly with $10.0 \mathrm{~mL}$ of $n$ butanol; the organic phase was collected into a $25 \mathrm{~mL}$ standard flask and made up to the mark with $n$-butanol. The absorbances of all the organic phases were recorded at $440 \mathrm{~nm}$, against their corresponding reagent blanks. The corresponding graph drawn between absorbance and mole fraction of the metal is shown in (Fig 2).

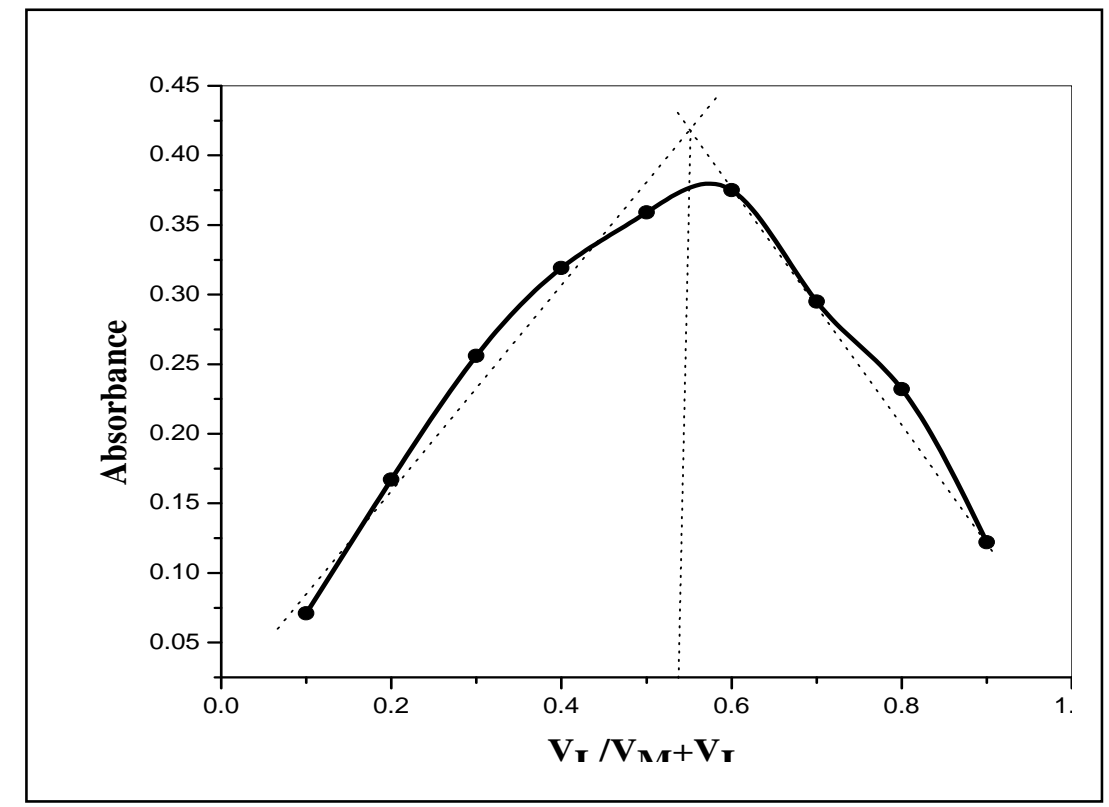

Figure 2.Job's method of continuous variation of $\mathrm{Cu}(\mathrm{II})$-APPT complex.Cu(II) or APPT, $2.95 \mathrm{x}$ $10^{-3} \mathrm{~mol} / \mathrm{L} ; \mathrm{pH}, 4.5 ; \lambda \max , 440 \mathrm{~nm}$.

\subsubsection{Molar Ratio Method}

Different aliquots of mixtures containing1.0 mL of $\left(0.98 \times 10^{-3} \mathrm{~mol} / \mathrm{L}\right)$ copper(II) and $3.0 \mathrm{~mL}$ of sodium acetate-acetic acid buffer ( $\mathrm{pH} 4.5)$ were prepared. To each of these solutions was added the required volume of reagent solution $\left(0.25-2.95 \times 10^{-3} \mathrm{~mol} / \mathrm{L}\right)$, and final volumes were made up to $10 \mathrm{~mL}$ of $n$-butanol; the organic phase was collected in a $25 \mathrm{~mL}$ standard flask and made 
up to the mark with $n$-butanol. The absorbances of the organic phases obtained were recorded at $440 \mathrm{~nm}$, against their corresponding reagent blanks.

\subsection{Effect of foreign ion}

The potential interference of diversions in the determination of copper(II) was studied by using $62.5 \mu \mathrm{g}$ of copper(II) and various amounts of each diverse ion in question. A given species was considered to be interfering if it resulted in a $2 \%$ variation of the absorbance, for the established level of copper(II) alone. Cations such as $\mathrm{Ca}(\mathrm{II}), \mathrm{Mg}(\mathrm{II}), \mathrm{Pb}(\mathrm{II}), \mathrm{Mn}(\mathrm{II})$, and $\mathrm{Bi}(\mathrm{III})$ do not interfere even when present up to $5000 \mu \mathrm{g}$. Interference due to $\mathrm{Al}(\mathrm{III}), \mathrm{Cr}$ (III), $\mathrm{Ag}$-(I), and $\mathrm{Sb}$ (II) can be tolerated up to $2500 \mu \mathrm{g}$, whereas Mo(VI)and W(V) can be tolerated up to $2000 \mu \mathrm{g}$ only. Extraction of copper(II) is not possible in the presence of $\mathrm{Co}(\mathrm{II}), \mathrm{Ni}(\mathrm{II}), \mathrm{Fe}-(\mathrm{II}), \mathrm{Fe}(\mathrm{III}), \mathrm{Zn}(\mathrm{II})$, $\mathrm{Pd}(\mathrm{II})$, and $\mathrm{Cd}(\mathrm{II})$, due to their interference, even when present in trace amounts. Anions such as fluoride, bromide, iodide, chloride, nitrate, sulfate, thiosulfate, citrate, acetate, and tartarate do not affect the extraction of copper(II), even when present up to $5000 \mu \mathrm{g}$. In the presence of thiocyanate, oxalate, and EDTA, extraction of copper(II) is not possible. One milliliter of $0.2 \%$ fluoride was used as a masking agent for Fe-(II) and $\mathrm{Fe}(\mathrm{III})$. Interference due to $\mathrm{Co}(\mathrm{II}), \mathrm{Ni}(\mathrm{II})$, $\mathrm{Zn}(\mathrm{II})$, Pd-(II), and $\mathrm{Cd}(\mathrm{II})$ can be suppressed by adding $1.0 \mathrm{~mL}$ of $0.2 \%$ citrate solution. Increasing the amounts of their corresponding masking agents proportionately can mask higher amounts of interfering ions.

Table 3. Copper(II) in leafy vegetables (Note: ${ }^{a}$ Average of four replicants, $\left.n=4\right)$.

\begin{tabular}{|c|c|c|c|c|c|}
\hline \multirow[b]{2}{*}{ Leafy vegetable } & \multicolumn{5}{|c|}{ Amount of Cu(II)found ${ }^{a}(\mu g / g)$} \\
\hline & $\begin{array}{l}\text { amount } \\
\text { added }(\mu \mathrm{g} / \mathrm{g})\end{array}$ & $\begin{array}{l}\text { AAS } \\
\text { method }\end{array}$ & $\begin{array}{l}\text { Present } \\
\text { method }\end{array}$ & $S D$ & $\begin{array}{l}R S D \\
(\%)\end{array}$ \\
\hline Cucumber (Cucumis sitivas) & 10.00 & 10.52 & 10.51 & 0.03 & 0.28 \\
\hline Green peas (Pisum sativum) & 10.00 & 11.15 & 11.14 & 0.05 & 0.43 \\
\hline Fresh bean (Dolichos lablab) & 10.00 & 10.88 & 10.87 & 0.04 & 0.37 \\
\hline White radish (Raphanus sativus) & 10.00 & 14.21 & 14.20 & 0.06 & 0.42 \\
\hline
\end{tabular}

\section{APPLICATIONS OF THE DEVELOPED METHOD}

The developed extractive spectrophotometric method for copper(II) was applied for the determination in leafy vegetable, pharmaceutical, and Bureau of Analyzed samples. 


\subsection{Determination of $\mathrm{Cu}(\mathrm{II})$ in Leafy Vegetable Samples}

The established optimized conditions of extractive spectrophotometric method were applied to leafy vegetables, for the determination of copper(II) content. The leafy vegetables analyzed were brought from the local market during the month of January. The samples were cleaned and dried in open air, protecting them from mineral contamination. The dried sample was pulverized in a mortar for the purpose of analysis, to a convenient size. Ten grams of each powdered sample was taken into a silica crucible, heated to oxidize the organic matter, and ashed at $550{ }^{\circ} \mathrm{C}$ in a muffle furnace for 4-5 h. The ash was dissolved by heating with $10 \mathrm{~mL} 2 \mathrm{~N}$ hydrochloric acid and filtered through an acid-washed filter paper (Whatman no. 41), and then the residue was washed with hot water. The filtrate and washings were collected in a $25 \mathrm{~mL}$ volumetric flask and finally made up to the mark with double-distilled water. An appropriate aliquot was analyzed for copper(II) by the recommended procedure using APPT from the leafy vegetable was extracted at $440 \mathrm{~nm}$. The process was repeated four times for each sample, and the results obtained were confirmed by direct atomic absorption spectrometer. The results obtained are presented in (Table 3).

\subsection{Determination of $\mathrm{Cu}(\mathrm{II})$ in Pharmaceutical Samples}

Pharmaceutical samples such as Supradyn, The sagram-M,Vimgram, and Fersolate were analyzed for copper(II). All of the pharmaceutical samples were brought into solution by adapting the following procedure. The samples were treated separately with concentrated nitric acid on a hot plate, at a low temperature, to avoid violent spurting. The residue of each sample was cooled, and again nitric acid was added. The temperature of the hot plate was kept low to avoid violent spurting. The residue of each sample was cooled, and again nitric acid was added. The temperature of the hot plate was increased to $300{ }^{\circ} \mathrm{C}$. The residue obtained was dissolved in nitricacid (1:1) and then slowly heated for $2 \mathrm{~h}$ to produce a dry mass. Finally the residue was dissolved in a minimum amount of double-distilled water. The same solution was quantitatively transferred into a $500 \mathrm{~mL}$ volumetric flask and then made upto the mark with double-distilled water. An appropriate aliquot was analyzed for copper(II) by the recommended procedure using APPT. The results obtained were confirmed by direct atomic absorption spectrometer and are presented in (Table 4). 
Table 4.Determination of Copper(II) in pharmaceutical samples (Note: ${ }^{a}$ Average of four replicants, $\mathrm{n}=4$; ${ }^{\mathrm{b}} \mathrm{IP}=$ Indian Pharmacopoeia; USP $=$ United States Pharmacopoeia; $\mathrm{c}$ $=$ Masked with phosphate.

\begin{tabular}{|c|c|c|c|c|c|}
\hline \multirow[t]{2}{*}{ Sample } & \multirow[t]{2}{*}{ Composition } & \multicolumn{4}{|c|}{ Amount of $\mathrm{Cu}(\mathrm{II})$ ) found ${ }^{a}(\mu \mathrm{g} / \mathrm{g})$} \\
\hline & & $\begin{array}{l}\text { AAS } \\
\text { method }\end{array}$ & $\begin{array}{l}\text { Present } \\
\text { method }\end{array}$ & $S D$ & $\begin{array}{l}R S D \\
(\%)\end{array}$ \\
\hline $\begin{array}{l}\text { Supradyn } \\
\text { (Roche Chemicals, } \\
\text { India) }\end{array}$ & $\begin{array}{l}\text { Copper sulfate } \mathrm{IPb} 3.39 \mathrm{mg} \text { (equivalent to } \\
\text { elemental copper, } 0.86 \mathrm{mg} \text { ); zinc sulfatec IP } \\
2.20 \mathrm{mg} \text {; sodium borateIP } 0.88 \mathrm{mg}\end{array}$ & 0.86 & 0.85 & 0.011 & 1.29 \\
\hline $\begin{array}{l}\text { Theragran-M } \\
\text { (Sarabhai } \\
\text { Chemicals, India) }\end{array}$ & $\begin{array}{l}\text { Potassium iodide IP } 0.2 \mathrm{mg} \text {; dried iron(II) } \\
\text { sulfatec IP } 41 \mathrm{mg} \text {; copper sulfate IP } 8 \mathrm{mg} \\
\text { (equivalent to elemental copper, } 0.86 \mathrm{mg} \text { ) }\end{array}$ & 2.00 & 1.99 & 0.013 & 0.65 \\
\hline $\begin{array}{l}\text { Vimgram } \\
\text { (Sarabhai } \\
\text { Chemicals, India) }\end{array}$ & $\begin{array}{l}\text { Calcium carbonate USP } 250 \mathrm{mg} \text {; iron(II) } \\
\text { sulfatec IP } 34 \mathrm{mg} \text {; potassium sulfate IP } 10 \\
\text { mg; copper sulfate IP } 4.0 \mathrm{mg} \text { (equivalent to } \\
\text { elemental copper, } 0.86 \mathrm{mg} \text { ); manganese } \\
\text { sulfate IP } 6.6 \mathrm{mg} \text {; magnesium oxide IP } 10.0 \\
\text { mg }\end{array}$ & 1.00 & 0.99 & 0.012 & 1.21 \\
\hline $\begin{array}{l}\text { Fersolate } \\
\text { (Glaxo, India) }\end{array}$ & $\begin{array}{l}\text { Iron(II) sulfatec IP } 195 \mathrm{mg} \text {; copper sulfate IP } \\
2.6 \mathrm{mg} \text { (equivalent to elemental copper, } 0.86 \\
\mathrm{mg} \text { ); manganese sulfate IP } 2.6 \mathrm{mg}\end{array}$ & 0.66 & 0.65 & 0.011 & 1.69 \\
\hline
\end{tabular}

Table 5.Determination of Copper(II) in Bureau of Analyzed Samples (Note: ${ }^{\text {a }}$ Average of four replicants $(\mathrm{n}=4){ }^{\mathrm{b}}$ Masked with phosphate)

\begin{tabular}{|c|c|c|c|c|c|}
\hline \multirow[t]{2}{*}{ Alloy } & \multirow[t]{2}{*}{ Composition } & \multicolumn{4}{|c|}{ Amount of Cu(II)found ${ }^{a}(\mu g / g)$} \\
\hline & & $\begin{array}{l}\text { AAS } \\
\text { method }\end{array}$ & $\begin{array}{l}\text { Present } \\
\text { method }\end{array}$ & $S D$ & $\begin{array}{l}R S D \\
(\%)\end{array}$ \\
\hline $\begin{array}{l}\text { Alloy steel (BCS } \\
\text { 233) }\end{array}$ & $\begin{array}{l}\mathrm{Cu}, 5.09 ; \mathrm{Co}^{\mathrm{b}}{ }^{23.4 ; \mathrm{Ni}^{\mathrm{b}}} \text { 11.22; } \mathrm{Sn}, \\
\text { 7.95; } \mathrm{Mn}, 0.235\end{array}$ & 5.00 & 4.98 & 0.045 & 0.90 \\
\hline $\begin{array}{l}\text { Alloy steel (BCS } \\
266)\end{array}$ & $\mathrm{Cu}, 3.33 ; \mathrm{Co}^{\mathrm{b}} 23.4 ; \mathrm{Ni}^{\mathrm{b}}{ }^{\mathrm{b}} 13.3 ; \mathrm{Al}, 7.95$ & 3.30 & 3.28 & 0.036 & 1.09 \\
\hline $\begin{array}{lr}\text { Aluminum } & \text { base } \\
\text { alloy } & \text { (BCS } \\
216 / 1) & \\
\end{array}$ & $\begin{array}{l}\mathrm{Cu}, 4.42 ; \mathrm{Mn}, 0.73 ; \mathrm{Fe},{ }^{b} 0.40 ; \mathrm{Zn}, \\
0.11 ; \mathrm{Ti}, 0.10\end{array}$ & 4.40 & 4.37 & 0.044 & 1.00 \\
\hline $\begin{array}{l}\text { Copper base alloy } \\
\text { (BCS 207) }\end{array}$ & $\mathrm{Cu}, 86.84 ; \mathrm{Sn}, 9.8 ; \mathrm{Zn},{ }^{\mathrm{b}} 2.53 ; \mathrm{Pb}, 0.41$ & 86.56 & 86.42 & 0.824 & 0.95 \\
\hline $\begin{array}{l}\text { Copper base alloy } \\
\text { (BCS 179) }\end{array}$ & $\begin{array}{l}\mathrm{Cu}, 58.8 ; \mathrm{Zn},{ }^{\mathrm{b}} 33.9 ; \mathrm{Sn}, 1.75 ; \mathrm{Al}, 1.62 ; \\
\mathrm{Mn}, 1.03 ; \mathrm{Ni}, \mathrm{b} 1.01 ; \mathrm{Fe}, \mathrm{b} 0.91\end{array}$ & 58.62 & 58.38 & 0.54 & 0.92 \\
\hline
\end{tabular}

\subsection{Determination of $\mathrm{Cu}(\mathrm{II})$ in Bureau of Analyzed Samples}

The proposed method was applied for the determination of copper(II) in Bureau of Analyzed Samples such as alloy steels (BCS 233 and 266), aluminum base alloy(BCS 216/1), and copper base alloys (BCS 207 and 179). About0.1 g of each oven-dried (110 ${ }^{\circ}$ ) alloy sample was dissolved in $15 \mathrm{~mL}$ of aqua-regia. The solution was heated to near dryness, and the nitrate was 
expelled from the residue, using $5.0 \mathrm{~mL}$ of concentrated hydrochloric acid. Each residue was then extracted into double-distilled water and made up to $500 \mathrm{~mL}$. An appropriate aliquot was analyzed for copper(II) by the recommended procedure using APPT. The results obtained were confirmed by direct atomic absorption spectrometer and are presented in (Table 5).

\section{CONCLUSION}

In the present investigation, the researchers have introduced a new reagent, 2-acetylpyridinel-4phenyl-3-thiosemicarbazone (APPT),for the extractive spectrophotometric determination of copper-(II). This method offers several interesting features such as simplicity, rapidity, and low cost besides sensitivity. The molar absorptivity value of the complex $\left(2.16 \times 10^{4} \mathrm{~L} \mathrm{~mol}^{-1} \mathrm{~cm}^{-1}\right)$ reveals that the reagent is more sensitive for copper(II) as compared with the earlier reagents. A number of associated elements do not interfere in the determination. The selectivity of the reagent is also improved by the use of suitable masking agents to suppress the interference of some metal ions such as $\mathrm{Co}(\mathrm{II}), \mathrm{Ni}(\mathrm{II}), \mathrm{Fe}(\mathrm{II}), \mathrm{Fe}(\mathrm{III}), \mathrm{Zn}(\mathrm{II}), \mathrm{Cd}(\mathrm{II})$, and $\mathrm{Pd}(\mathrm{II})$. Finally, APPT is strongly recommended for the extractive spectrophotometric determination of copper(II) at minor and trace levels besides its use for the analysis of leafy vegetable and pharmaceutical samples, as described.

\section{ACKNOWLEDGEMENT}

The authors thank Mr. G. Ramachandra Reddy and Mr. A. Babul Reddy for their immense help in carrying out my research investigations. I would also like to acknowledge UGC-SAP (Government of India)for providing financial assistance in the form of Junior Research fellowship.

\section{REFERENCES}

Casas, J. S., Garcia-Tasende, M. S \& Sordo, J. 2000. Main group metal complexes of semicarbazones and thiosemicarbazones: A structural review. Coord. Chem. Rev., 209:197-261. 
Cristofol, E. J., Sanchez Rojas, F \& Cano Pavon, J. M. 1991. Evaluation of various $N$ phenylthiosemicarbazones as chromogenic reagents in spectrophotometric analysis. Talanta, 38: 445-448.

Desai, J. M \& Desai, K. K. 1999. Spectrophotometric determination of copper(II) and iron(II)with 2,4,dihydroxy-5-bromoacetophenonethiosemicarbazone.Asian J. Chem.,11: 1311-1316.

Hall, I. H., Lackey, C. B., Kistler, T. D., Durham, R. W., Jouad,E. M., Khan, M., Thanh, X. D.,Djebbarsid, S., Benali Baitich, O \& Bouet, G. M.2000. Cytotoxicity of copper and cobalt complexes of fural semicarbazone and thiosemicarbazone derivatives in urine and human tumor cell lines. Pharmazie, 55: 937-941.

Jadhav, V. A \& Vandre, A. G. 1995. 8-Methoxy-2-chloroquinoline-3-carbaldehyde thiosemicarbazone as an analytical reagent for cobalt(II) and copper(II). J. Indian Chem.Soc.,72: 747-748.

Khasnis, D. V \& Shinde, V. M. 1982. Determination of copper in steel, brass, gunmetal, nickelsilver and aluminium alloy by extraction with phenanthraquinone monothiosemicarbazone. JournalIndian Chem.Soc., 59 (6): 812-814.

Khasnis, D. V \& Shinde, V. M. 1984. A new method for extractive photometric determination of copper and iron in alloy steel. J.Indian Chem. Soc., 61: 275-277.

Lokhande, R. S., Poman, S. V \& Kapadi, H. R. 2001. Extractivespectrophotometricdetermination of $\mathrm{Cu}(\mathrm{II})$ with 4-chloro-iso-nitrosoacetophenonethiosemicarbazone. Asain J.Chem., 13: 1222-1224.

Lopez-de-Alba, P., Loper-Martiney, L \& Amador-Hernandez.1999. Spectrophotometric determination of copper in medical formulations: wheat bran and drinking water. Bol.Soc. Chil. Quim., 44: 469-477.

Malvankar, P. L \& Shinde, V. M. 1991.Ion-pair extraction and determination of copper(II) and zinc(II) in environmental and pharmaceutical samples. Analyst, 116:1081-1084.

Patel, A. L \& Patel, I. J.2000.Spectrophotometric determination of Cu-(II) with benzaldehyde-4(2-hydroxy-5-sulfophenyl)-3-thiosemicarbazone(BHST). Indian J. Inst. Chem.,72:8. 
Reddy, B. K., Kumar, J. R., Reddy, K. J., Sarma, L. S \& Reddy, A. V. 2002. Sensitive extractive spectrophotometric determination of zinc(II) in biological and environmental samples using benzyldithiosemicarbazone. Anal.Lett., 35: 1415-1427.

Reddy, B. K., Kumar, J. R., Reddy, K. J., Sarma, L. S \& Reddy,A. V. 2003. A rapid and sensitive extractive spectrophotometric determination of copper(II) in pharmaceutical and environmental samples using benzyldithio-semicarbazone. Anal. Sci.,19:423-428.

Sarma, L. S., Kumar, J. R., Reddy, K. J., Kumar, A. K \& Reddy, A. V. 2002.A rapid and sensitive extractive spectrophotometric determination of palladium(II) in synthetic mixtures and hydrogenation catalysts using pyridioxal-4-phenyl-3-thiosemicarbazone. Anal. Sci., 18: 1257-1261.

Singh, R. B., Garg, B. S \& Singh, R. P. 1978. Analytical applications of thiosemicarbazones and semicarbazones: A review. Talanta, 25: 619-632.

Sarma, L. S., Kumar, J. R., Kumar, C. K \& Reddy, A. V. 2003. A sensitive extractive spectrophotometric determination of cobalt-(II) in real samples using pyridoxal-4-phenyl3-thiosemicarbazone.Anal.Lett., 36: 605-618.

Sarma, L. S., Ramesh, G. N., Kumar, C. J \& Reddy, A. V. 2000. Sensitive extractive spectrophotometric determination of iron-(III) with pyridoxal-4-phenyl-3thiosemicarbazone. J. Indian Chem. Soc., 77: 405-406.

Thimmaiah, K. N., Sanke Gowda, H. S \& Ahmed, M. 1983. Spectrophotometric determination of palladium(II) and copper(II) with $p$-anisaldehydethiosemicarbazone: analysis of alloy and minerals. Indian J. Chem.,22: 690-692.

Tongsen, M., Meng, L., Congde, H., Kuaizhi, L., Zhenghao, L \& Daxuesuebao, Z.1999. Spectrophotometric study on $\mathrm{Cu}(\mathrm{II})$ with pyruvaldehide (N,N1-dibutyl) bisThiosemicarbazone. Ziaru Keruebau. 31: 70-72.

Vogel, A. I. 1961. A Textbook of Quantitative Inorganic Analysis. Longman Green: London, U.K.

Walravens, P. A. 1980. Nutritional importance of copper and zinc in neonates and infants. Clin.Chem., 26: 185-189. 